\title{
Feed utilization, blood metabolites and ingestive behavior in Sahiwal calves divergently selected for low and high residual feed intake
}

\author{
Anil K. Singh, Muneendra Kumar*, Vinod Kumar, Debashis Roy, \\ Raju Kushwaha, Shalini Vaswani, and Avinash Kumar
}

Department of Animal Nutrition, College of Veterinary Science and Animal Husbandry, U.P. Pandit Deen Dayal Upadhyaya Pashu-Chikitsa Vigyan Vishwavidyalaya Evam Go-Anusandhan Sansthan, Mathura, India

SINGH, A. K., M. KUMAR, V. KUMAR, D. ROY, R. KUSHWAHA, S. VASWANI, A. KUMAR: Feed utilization, blood metabolites and ingestive behavior in Sahiwal calves divergently selected for low and high residual feed intake. Vet. arhiv 89, 481$503,2019$.

\section{ABSTRACT}

This study aimed to evaluate differences in feed utilization between low and high residual feed intake (RFI) in Sahiwal calves by comparing performance, ingestive behavior and blood metabolites. Eighteen, growing, female Sahiwal calves (aged 10-14 months; body weight (BW) 100-125 kg) were fed ad libitum on a total mixed ration for $90 \mathrm{~d}$. RFI varied from -0.53 to $0.40 \mathrm{~kg}$ dry matter (DM)/d with a mean RFI of -0.27 to $0.17 \mathrm{~kg} \mathrm{DM} / \mathrm{d}$ in low and high RFI Sahiwal calves, respectively. Calves with low RFI consumed $26 \%$ less DM and required 35\% less metabolizable energy for body maintenance (MEm) compared to high RFI, yet gained at a similar rate. Low RFI calves digest feed more efficiently than less efficient calves. Conventional efficiency measures also showed better efficiency in low RFI than high RFI calves. Low RFI calves spent less time in feeding, rumination, and chewing. Higher plasma concentrations of insulin-like growth factor-1 (IGF1), growth hormone $(\mathrm{GH})$, and creatinine, and lower concentrations of albumin, plasma urea nitrogen (PUN), and triglycerides were observed in the low RFI group than the high RFI group. However, plasma total protein, glucose, cholesterol, non esterified fatty acid (NEFA), beta-hydroxy butyric acid (BHBA), calcium (Ca), and phosphorus (P) concentrations were similar in both groups. In summary, low RFI calves utilized feed more efficiently by spending less time and energy in feeding, and the variability in blood metabolites might be due to differences in body metabolism.

Key words: efficiency; ingestive behavior; plasma metabolites; residual feed intake; Sahiwal

\footnotetext{
*Corresponding author:

Assist. Prof. Muneendra Kumar, Department of Animal Nutrition, College of Veterinary Science and Animal Husbandry, DUVASU, Mathura 281001, India, Phone: +91 904554 6435; E-mail: muneendra82@gmail.com
} 


\section{A. K. Singh et al.: Efficiency of calves varying in RFI}

\section{Introduction}

In spite of achieving the highest milk production, the performance of Indian cattle has been extremely poor. Poor performance of indigenous cattle is due to late age of maturity, thus they consume a large amount of feed before attaining sexual maturity. Feed costs for maintenance alone are estimated to represent at least 60 to $65 \%$ of the total feed requirements for the cow herd size (NIANP, 2013). Improving feed utilization efficiency and selection of energetically efficient animals could help in reducing the burden of already scarce feed resources, particularly in developing countries (NKRUMAH et al., 2006). Earlier, genetic selection programs focused on production traits, with lesser attention given to production costs. Recently, this view has begun to change, and the efficiency of conversion of feed has been recognized as a more important tool.

Several measures of feed efficiency calculated as a function of individual intake and body weight gain have been proposed over the years, in an attempt to quantify the capacity of animals to convert the ingested feed into a product. Selection, based on traditional measures such as feed conversion ratio (FCR) and feed conversion efficiency (FCE), is most common. Selection based on these measures is closely associated with feed intake and rate of gain (KOOTS et al., 1994), which may result in a higher mature body weight, that may not be desirable in many circumstances (ARCHER et al., 1998). Therefore, residual feed intake (RFI) was introduced as an alternate measure of feed efficiency. RFI is referred to as net feed efficiency and it is defined as the difference between actual feed intake and predicted feed intake, on the basis of the requirements for maintenance and current level of production (KOCH et al., 1963). It has been found that low RFI cattle have multiple benefits, such as decreased feed intake, less manure production and less methane emission (NKRUMAH et al., 2006; HEGARTY et al., 2007).

The biological basis contributing to the variations in RFI includes ingestive behavior, intake of feed, digestion of feed and associated energy use, metabolism, including anabolism and catabolism, activity and thermoregulation (NGUYEN et al., 2005). Low and high RFI animals differ in their feeding patterns, a fact that is mainly due to differences in the amount of feed ingested and rumination time (MISSIO et al., 2010). The differences in growth mechanisms between RFI groups were found in low RFI animals to be based on themhaving higher concentrations of insulin like growth hormone-1 (IGF-1), influencing their growth and feed efficiency. As RFI decreases, the efficiency of muscle accretion will improve, while fat deposition will decrease as characterized by decreased concentrations of urea and increased concentrations of creatinine (KNOTT et al., 2010). Higher triglyceride concentrations in high RFI animals are attributed to greater energy requirements of muscle due to the greater protein turnover rate (RICHARDSON et al., 2004). The identification of low RFI farm animals, and ultimately using them for breed 
improvement programmes, can go a long way towards the objectives of breed improvement and efficient nutrient utilization. Considering these facts, the present study was therefore designed to investigate the performance of Sahiwal calves divergently selected for low and high RFI. The hypothesis of the present study is that RFI was related to feed efficiency and performance, and that differences exist between calves with divergent RFI.

\section{Materials and methods}

The use of the animals and the experimental procedure was approved by the Institutional Animal Ethics Committee (IAEC) constituted as per the Article 13 of the rules of the Committee for the Purpose of Control and Supervision on Experiments on Animals (CPCSEA), laid down by the Government of India (approval no. 110/ IAEC/16).

Experimental design and animal management. Eighteen growing female Sahiwal calves were selected from the herd maintained at Livestock Farm Complex (ILFC), DUVASU, Mathura, India. The calves were fed ad libitum on a TMR based diet consisting of a concentrate mixture: green oat fodder: wheat straw in the proportion of 50:20:30 (DM basis) for a period of $90 \mathrm{~d}$, based on the recommendations of ARCHER et al. (1997) for the optimum test duration for measuring RFI. TMR was prepared daily by hand mixing separately for each calf, and contained $12.80 \%$ crude protein (CP), $57.20 \%$ total digestible nutrient (TDN) and 2.16 Mcal metabolizable energy (ME)/kg DM (Table 1). Two daily meals of TMR were offered at 09:00 $\mathrm{h}$ and 18:00 $\mathrm{h}$ in all tests. The calves were fed the TMR in such an amount that at least $1 \mathrm{~kg}$ residual were left daily per calf. Fresh drinking water was offered ad libitum twice daily at 08:00 $\mathrm{h}$ and 17:00 h.

Table 1. Ingredient and chemical composition of TMR fed during the experimental period (expressed as $\mathrm{g} / \mathrm{kg}$ of DM unless otherwise stated)

\begin{tabular}{|l|c|c|}
\hline Item & Concentrate & TMR \\
\hline Oat fodder & & 200 \\
\hline Wheat straw & & 300 \\
\hline Concentrate & 200 & 500 \\
\hline Barley grain & 200 & \\
\hline Wheat grain & 80 & \\
\hline Gram chuni & 200 & \\
\hline Wheat bran & 300 & \\
\hline Mustard oil cake & 20 & \\
\hline Mineral mixture & & \\
\hline
\end{tabular}

TMR, total mixed ration; TDN, total digestible nutrients; ME, metabolizable energy (as per NRC, 2001) 


\section{A. K. Singh et al.: Efficiency of calves varying in RFI}

Table 1. Ingredient and chemical composition of TMR fed during the experimental period (expressed as $\mathrm{g} / \mathrm{kg}$ of DM unless otherwise stated) (continued)

\begin{tabular}{|c|c|}
\hline \multicolumn{2}{|l|}{ Chemical composition } \\
\hline Dry matter & 748 \\
\hline Crude protein & 128 \\
\hline Acid insoluble ash & 48 \\
\hline Ether extract & 32.7 \\
\hline Neutral detergent fibre & 473.2 \\
\hline Acid detergent fibre & 291.1 \\
\hline Acid detergent lignin & 47.5 \\
\hline Calcium & 10 \\
\hline Phosphorus & 4.80 \\
\hline TDN & 572 \\
\hline ME, Mcal/kg DM & 2.16 \\
\hline
\end{tabular}

TMR, total mixed ration; TDN, total digestible nutrients; ME, metabolizable energy (as per NRC, 2001)

A collection period of $6 \mathrm{~d}$ was conducted at the end of the study. TMR offered and residual left were sampled daily for chemical analysis. Faeces excreted over $24 \mathrm{~h}$ were collected and measured daily for $6 \mathrm{~d}$.

Observation recorded. The experimental calves were monitored daily for dry matter intake (DMI) and fortnightly for growth performance, feed efficiency measures and ingestive behavior. Feed offered and residual left were weighed daily, sampled twice per week, and pooled to represent each period of $90 \mathrm{~d}$ for DM determination. DMI was calculated as the difference between the amount offered and residual left. To increase the accuracy of the estimation of average daily gain (ADG), calves were weighed at fortnightly intervals in the early morning $(06: 00 \mathrm{~h})$ before being offered feed and water. Along with RFI, calves were also monitored fortnightly for FCR (feed-to-gain-ratio), FCE (gain-to-feed-ratio), Kleiber ratio (KR), partial efficiency of growth (PEG), body condition score (BCS) and relative growth rate (RGR). KR was calculated as the ratio between ADG and the average metabolic body weight; PEG was calculated as the ratio between ADG per unit of feed used for growth (NRC, 2001). The BCS of the experimental calves was scored as per the five point scale given by ANITHA et al. (2005), and RGR using the equation described by FITZHUGH and TAYLOR (1971):

$$
\mathrm{RGR}=100 \times \frac{(\log \text { Final BW }-\log \text { Initial BW })}{\text { days of experiment }}
$$

In the middle of the study, ingestive behavior was determined by monitoring the calves for feeding, chewing, rumination, idleness, standing and lying. The behavioral 
events were recorded manually by four trained observers. Feeding time (FT; min/d) was counted as the total time spend by a calf consuming TMR over $24 \mathrm{~h}$. Three rumen boluses per calf were observed during rumination, and the number and time of chewing per bolus was counted as chewing rate (CT). Rumination time (RT) was the total time in $24 \mathrm{~h}$ during which the calf ruminated. Time spent on idleness (TI) was calculated by deducting the duration of events $(\mathrm{min} / \mathrm{d})$ from the total duration of the day $(1440 \mathrm{~min})$. To determine the time of activity spent on the diet (min/kg DM) such as feeding time per $\mathrm{kg} \mathrm{DM}$ (FTDM), rumination time per kg DM (RTDM) and chewing time per kg DM (CTDM), the total duration of these activities was divided by the total amount of feed consumed.

Determination of $A D G, R F I$ and $M E$. ADG was determined using the linear regression coefficient of weights as a function of days in the trial, according to ARCHER et al. (1997):

$$
y_{i}=\alpha+\beta \times D I T_{i}+e_{i}
$$

where: $y_{i}$ is the calves' bodyweight in the $i^{\text {th }}$ observation, $\alpha$ is the intercept of the regression equation corresponding to the initial body weight, $\beta$ is the linear regression coefficient corresponding to ADG, DIT is the days in trial on the $i^{\text {th }}$ observation and $e_{i}$ is the random error. Mid-test metabolic body weight (MBW) was calculated using the following equation:

$$
M B W=[\alpha+\beta \times \text { study period } / 2]^{0.75}
$$

where, $\alpha$ is the intercept of the regression equation corresponding to the initial body weight and $\beta$ is the linear regression coefficient corresponding to ADG. The calves were classified into low (negative) and high (positive) RFI groups. RFI was calculated using the following formula:

\section{$R F I(\mathrm{~kg} / \mathrm{d})=$ Actual DMI $(\mathrm{kg} / \mathrm{d})$ - Predicted DMI $(\mathrm{kg} / \mathrm{d})$}

The amounts of DM offered and residual left were measured daily, and the actual DMI was calculated by the difference. The predicted DMI of each individual calf was calculated using the multiple regression model:

$$
Y_{j}=\beta_{0}+\beta_{i} M B W j+\beta_{i} A D G j+e_{j}
$$

where, $Y_{j}$ is the predicted DMI of the $j^{\text {th }}$ animal, $\beta_{0}$ is the regression intercept, $\beta_{1}$ is the regression coefficient of $M B W, \beta_{2}$ is the regression coefficient of $\mathrm{ADG}, e_{j}$ is the uncontrolled error of the $j^{\text {th }}$ animal. ME requirements were calculated as per the NRC (2001) feeding standard. Observed and required MEm and MEg were calculated by the following equations (SHARMA et al., 2016):

MEI observed $(\mathrm{Mcal} / \mathrm{d})=\mathrm{DMI} \times \mathrm{ME}$ offeed

where, $M E I$ is the metabolizable energy intake and $D M I$ is the dry matter intake.

MEm observed $(\mathrm{Mcal} / \mathrm{d})=\mathrm{MEI}$ observed - MEg observed

where, $M E m$ is the metabolizable energy for maintenance and $M E g$ is the metabolizable energy for gain. 
MEm required $(\mathrm{Mcal} / \mathrm{d})=122 \times B W^{0.75} / 1000$

$M E g$ observed $\left.(\mathrm{Mcal} / \mathrm{d})=\left(4.1+0.0332 \times W-0.000009 \times W^{2}\right)\right) /(1-0.1475 \times W G)$

where, $W$ is the live weight $(\mathrm{kg})$ and $W G$ is the live weight gain $(\mathrm{kg} / \mathrm{d})$.

$M E g$ required $(\mathrm{Mcal} / \mathrm{d})=\mathrm{MEI}$ required $-\mathrm{MEm}$ required

Laboratory analyses. The representative samples of TMR offered, residues left and faeces were pooled animal-wise and analysed for DM (Method 973.18c), CP (Method 4.2.08), ether extract (EE; Method 920.85) and acid insoluble ash (AIA; Method 923.03) (AOAC, 2005). Neutral detergent fibre (NDF), acid detergent fibre (ADF) and acid detergent lignin (ADL) were determined according to the method of VAN SOEST et al. (1991). Ca and P content were determined by the titration method (TALPATRA et al., 1940) and spectrophotometric method, respectively.

Peripheral blood samples were collected in heparinised vacuutainer tubes (BD Franklin, USA) at the start, middle and end of the study. Immediately after collection, the tubes were kept in ice, transported to the laboratory and centrifuged at $1200 \mathrm{~g}$ at $4{ }^{\circ} \mathrm{C}$ for $20 \mathrm{~min}$ to separate the plasma from the packed erythrocytes. Plasma samples were stored at $-20{ }^{\circ} \mathrm{C}$ until further analysis of blood metabolites and hormones. Plasma levels of IGF-1 and GH were determined using bovine specific "IGF-1 (Catalog no. E0016Bo)" and "GH (Catalog no. E0017Bo)" ELISA Test Kits (Bioassay Technologies, Shanghai, China). Plasma levels of total protein, albumin, PUN, creatinine, glucose, triglycerides, cholesterol, $\mathrm{Ca}$ and $\mathrm{P}$ were determined colorimetrically by an automated biochemical analyzer (BS-120 Chemistry Analyzer, Shenzhen Mindray Biochemical Electronics Co. Ltd.) using Autospan liquid Gold test kits. The copper soap solvent extraction method, modified by SHIPE et al. (1980), was adopted for estimation of plasma NEFA concentration. BHBA was analyzed by the distillation method described by WEICHSELBAUM and SOMOGYI (1941).

Statistical analyses. The data were analysed for significance and correlation coefficient (r) using the Statistical Package for the Social Sciences (SPSS for Windows, V21.0; SPSS Inc., Chicago, IL, USA). Significance was analysed using one way analysis of variance (ANOVA). An alpha level of 0.05 was used for determination of statistical significance. A greater $(r>0)$ or lower $(r<0)$ than zero value of the Pearson square correlation coefficient (r) shows a positive or negative correlation between RFI and attributes whereas, a zero $(\mathrm{r}=0)$ value of the Pearson square correlation coefficient shows no correlation between RFI and attributes.

\section{Results}

Performance and nutrient digestibility. Significant differences $(\mathrm{P}<0.05)$ between low and high RFI calves were observed for feed intake, with low RFI calves consuming $26 \%$ 
less DM than the calves in the high RFI group (Table 2). The difference in observed and required DMI (RFI) was on average $0.17 \mathrm{~kg} / \mathrm{d}$ and $-0.27 \mathrm{~kg} / \mathrm{d}$ in the low and high RFI groups, respectively. The least efficient calf consumed $0.930 \mathrm{~kg} \mathrm{DM} / \mathrm{d}$ more feed than the most efficient calf. Out of 18 calves, the observed DMI of eleven calves was lower than the expected DMI (negative or low RFI), whereas that of the remaining seven calves was higher than the expected DMI (positive or high RFI) (Fig. 1). ADG was statistically similar among low and high RFI calves.

Table 2. Nutrient intake and nutrient digestibility in low and high RFI calves

\begin{tabular}{|c|c|c|c|c|c|}
\hline \multirow[b]{2}{*}{ Attributes } & \multicolumn{2}{|c|}{ RFI, $\mathrm{kg} \mathrm{DM} / \mathrm{d}$} & \multirow[b]{2}{*}{ SEM } & \multirow[b]{2}{*}{$P$-value ${ }^{\beta}$} & \multirow[b]{2}{*}{$\mathrm{r}^{¥}$} \\
\hline & Low $(-0.27)$ & High $(0.17)$ & & & \\
\hline Animal No. & 11 & 7 & & & \\
\hline Days in trial & 90 & 90 & & & \\
\hline Initial BW, kg & 85 & 114 & 5.64 & 0.003 & 0.652 \\
\hline Mid-test BW, kg & 108 & 137 & 5.89 & 0.028 & 0.659 \\
\hline Final BW, kg & 135 & 165 & 6.05 & 0.002 & 0.669 \\
\hline MBW, kg & 33.50 & 46.04 & 1.57 & 0.003 & 0.667 \\
\hline DMI, kg/d & $3.01^{\mathrm{a}}$ & $4.06^{\mathrm{b}}$ & 0.38 & $<0.001$ & 0.756 \\
\hline DMIBW, kg/100 kg BW & 2.95 & 3.01 & 0.08 & 0.072 & 0.293 \\
\hline DCPI, $\mathrm{kg} / \mathrm{d}$ & $0.348^{\mathrm{a}}$ & $0.456^{\mathrm{b}}$ & 0.03 & 0.002 & 0.673 \\
\hline ME intake observed, Mcal/d & $6.50^{\mathrm{a}}$ & $8.77^{\mathrm{b}}$ & 0.34 & $<0.001$ & 0.756 \\
\hline MEm observed, Mcal/d & $4.09^{\mathrm{a}}$ & $6.28^{\mathrm{b}}$ & 0.30 & $<0.001$ & 0.767 \\
\hline MEg observed, Mcal/d & 2.41 & 2.49 & 0.05 & 0.085 & 0.417 \\
\hline $\mathrm{ADG}, \mathrm{kg} / \mathrm{d}$ & 0.549 & 0.570 & 0.02 & 0.346 & 0.191 \\
\hline \multicolumn{6}{|c|}{ Apparent nutrient digestibility, g/kg DM } \\
\hline Dry matter & $623^{\mathrm{b}}$ & $580^{\mathrm{a}}$ & 7.60 & 0.015 & -0.351 \\
\hline Organic matter & $648^{\mathrm{b}}$ & $604^{\mathrm{a}}$ & 4.62 & 0.039 & -0.212 \\
\hline Crude protein & $712^{b}$ & $679^{\mathrm{a}}$ & 9.70 & 0.010 & -0.393 \\
\hline Ether extract & 829 & 801 & 6.30 & 0.319 & -0.547 \\
\hline Neutral detergent fibre & $547^{\mathrm{b}}$ & $516^{\mathrm{a}}$ & 13.2 & 0.021 & -0.090 \\
\hline Acid detergent fibre & $483^{b}$ & $447^{\mathrm{a}}$ & 18.5 & 0.047 & -0.007 \\
\hline
\end{tabular}

${ }^{\beta}$ Mean with different superscript in a row differs significantly $(\mathrm{P}<0.05) ;{ }^{\ddagger}$ Pearson square correlation coefficient between RFI and attributes; RFI - residual feed intake; SEM - standard error of mean; BW - body weight; MBW - mid-test metabolic body weight; DMI - dry matter intake; DMIBW - dry matter intake in relation to body weight; DCPI - digestible crude protein intake (estimated during digestion trial); MEm - metabolizable energy for maintenance (as per NRC - 2001); MEg - metabolizable energy for gain; ADG - average daily gain 
A. K. Singh et al.: Efficiency of calves varying in RFI

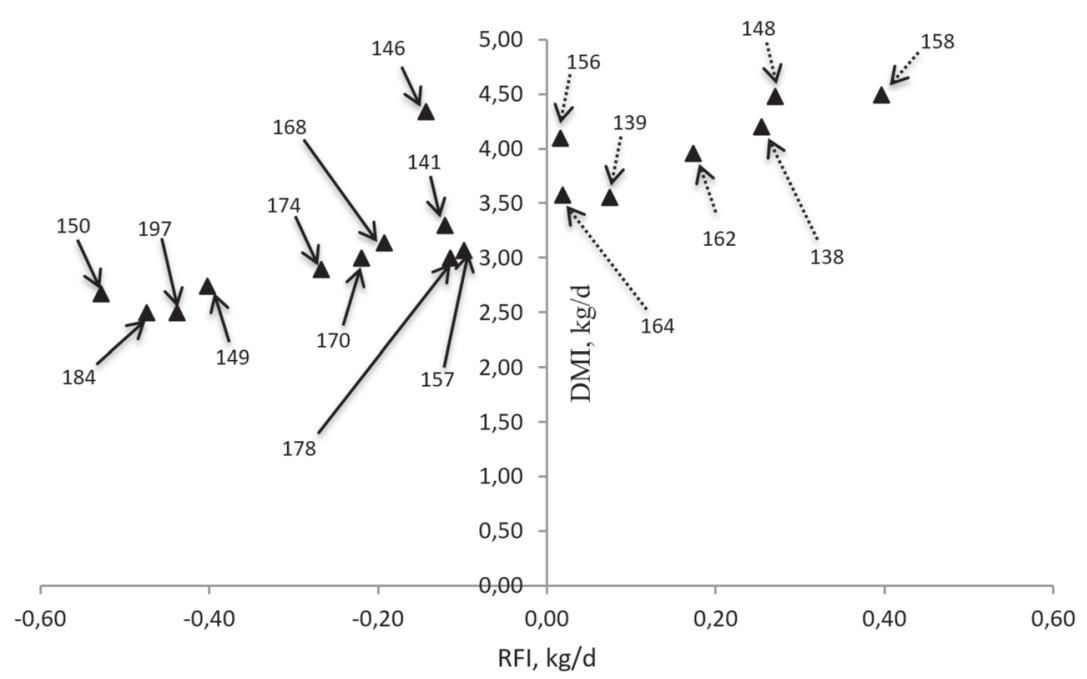

Fig. 1. DMI in low and high RFI Sahiwal calves. The observed DMIs of 11 calves were lower than the expected DMI (negative RFI) and higher in 7 calves than the expected DMI (positive RFI).

The total ME intake observed and ME used for body maintenance (MEm) were significantly higher $(\mathrm{P}<0.001)$ in high RFI calves than low RFI calves (Table 2$)$ but the MEg observed in low and high RFI calves were similar.

Significant differences $(\mathrm{P}<0.05)$ between low and high RFI calves were observed for nutrient digestibility. Digestibility of DM, CP and NDF in low RFI calves was 7,5 and 6\% higher compared to high RFI calves (Table 2).

In this study, medium to high positive correlations were observed among RFI and DMI $(r=0.756)$, MEm observed $(r=0.767)$ and MEg observed $(r=0.417)$, while the correlation with ADG $(r=0.191)$ was weak. The correlation between RFI and nutrient digestibility was weak to medium.

Feed efficiency measures and ingestive behavior. Calves in the low and high RFI group showed significant differences in FCR $(\mathrm{P}=0.002)$, FCE $(\mathrm{P}=0.002), \mathrm{KR}(\mathrm{P}=$ $0.004)$ and RGR $(P=0.013)$, however no significant differences between groups were observed for BCS $(\mathrm{P}=0.153)$ and $\mathrm{PEG}(\mathrm{P}=0.995)$ (Table 3$)$. RFI showed a significant $(\mathrm{P}<0.05)$ negative correlation with FCE $(\mathrm{r}=-0.668), \mathrm{KR}(\mathrm{r}=-0.645)$, RGR $(\mathrm{r}=-0.575)$ and a positive correlation with FCR $(r=0.670)$, PEG $(r=0.019)$ and BCS $(r=0.351)$. 
A. K. Singh et al.: Efficiency of calves varying in RFI

Table 3. Measures of feed efficiency and ingestive behavior in low and high RFI calves

\begin{tabular}{|c|c|c|c|c|c|}
\hline \multirow[b]{2}{*}{ Attributes } & \multicolumn{2}{|c|}{ RFI, $\mathrm{kg} \mathrm{DM} / \mathrm{d}$} & \multirow[b]{2}{*}{ SEM } & \multirow[b]{2}{*}{ P-value ${ }^{\beta}$} & \multirow[b]{2}{*}{$1^{*}$} \\
\hline & Low & High & & & \\
\hline \multicolumn{6}{|l|}{ Feed efficiency measures } \\
\hline RFI, kg DM/d & -0.27 & 0.17 & & & \\
\hline Feed conversion ratio & $5.51^{\mathrm{a}}$ & $7.28^{\mathrm{b}}$ & 0.4 & 0.002 & 0.670 \\
\hline Feed conversion efficiency & $0.20^{\mathrm{b}}$ & $0.15^{\mathrm{a}}$ & 0.01 & 0.002 & -0.668 \\
\hline Kleiber ratio & $0.014^{\mathrm{b}}$ & $0.01^{\mathrm{a}}$ & 0.001 & 0.004 & -0.645 \\
\hline Relative growth rate & $0.16^{\mathrm{b}}$ & $0.11^{\mathrm{a}}$ & 0.01 & 0.013 & -0.575 \\
\hline Body condition score & 2.55 & 2.75 & 0.17 & 0.153 & 0.351 \\
\hline Partial efficiency of growth & 2.90 & 2.85 & 0.36 & 0.995 & 0.019 \\
\hline \multicolumn{6}{|l|}{ Ingestive behavior, $\mathrm{min} / \mathrm{d}$} \\
\hline Feeding time & 272 & 293 & 4.30 & 0.039 & 0.134 \\
\hline FTDM, min/kg DM & 90.37 & 72.17 & 3.93 & 0.006 & -0.619 \\
\hline Rumination time & 346 & 438 & 8.30 & 0.047 & 0.229 \\
\hline RTDM, min/kg DM & 114.91 & 107.88 & 9.37 & 0.583 & -0.593 \\
\hline Chewing time & 618 & 731 & 11.20 & 0.036 & 0.178 \\
\hline CTDM, min/kg DM & 205.32 & 180.05 & 5.19 & 0.048 & -0.394 \\
\hline Time spent on idleness, $\mathrm{min} / \mathrm{d}$ & 822 & 709 & 10.50 & 0.035 & -0.231 \\
\hline
\end{tabular}

${ }^{\beta}$ Mean with different superscript in a row differs significantly $(\mathrm{P}<0.05)$; ${ }^{¥}$ Pearson square correlation coefficient; RFI - residual feed intake; SEM - standard error of mean; FTDM - feeding time $\mathrm{kg}^{-1}$ dry matter; RTDM rumination time $\mathrm{kg}^{-1}$ dry matter; CTDM - chewing time $\mathrm{kg}-1$ dry matter

Significant differences between low and high RFI calves were observed for most of the ingestive behavior variables studied (Table 3). High RFI calves consumed more feed than more efficient (low RFI) calves, and therefore spent more time in feeding ( $\mathrm{P}$ $=0.039)$, rumination $(\mathrm{P}=0.047)$ and chewing $(\mathrm{P}=0.036)$. The time of activity spent on the diet i.e. FTDM and CTDM $(\mathrm{min} / \mathrm{kg} \mathrm{DM})$ was significantly $(\mathrm{P}<0.05)$ higher in low RFI calves compared to high RFI calves. Low RFI calves spent more $(\mathrm{P}=0.035)$ time resting (idleness) than less high RFI calves. RFI showed a positive correlation with FT ( $\mathrm{r}$ $=0.134)$, RT $(r=0.229)$ and $\mathrm{CT}(\mathrm{r}=0.134)$ but a negative correlation with $\mathrm{TI}(\mathrm{r}=-0.231)$. The correlation between RFI and time of activity spent on the diet was medium to high, including -0.619 with FTDM, -0.593 with RTDM and -0.394 with CTDM.

RFI and plasma metabolites. Analysis of plasma metabolites showed higher concentrations of IGF-1 $(\mathrm{P}=0.028)$, GH $(\mathrm{P}<0.001)$ and creatinine $(\mathrm{P}=0.013)$ in low RFI calves compared to high RFI calves (Table 4). In contrast, lower concentrations of 
A. K. Singh et al.: Efficiency of calves varying in RFI

albumin $(\mathrm{P}<0.001)$, PUN $(\mathrm{P}=0.031)$ and triglycerides $(\mathrm{P}=0.045)$ were observed in low RFI calves compared to high RFI calves. No significant $(\mathrm{P}>0.05)$ differences between low and high RFI groups were observed for other studied blood metabolites. The RFI was negatively correlated with IGF-1, GH, total protein, PUN, creatinine, glucose, and BHBA and positively correlated with albumin, cholesterol, triglycerides, NEFA, Ca, and P concentration.

Table 4. Plasma metabolites in low and high RFI Sahiwal calves

\begin{tabular}{|c|c|c|c|c|c|c|}
\hline \multirow[b]{2}{*}{ Attributes } & \multicolumn{2}{|c|}{ RFI, $\mathrm{kg} \mathrm{DM} / \mathrm{d}$} & \multirow[b]{2}{*}{ SEM } & \multirow[b]{2}{*}{ P-value ${ }^{\beta}$} & \multirow[b]{2}{*}{$\mathrm{r}^{z}$} & \multirow[b]{2}{*}{ Range ${ }^{\epsilon}$} \\
\hline & Low -0.27$)$ & High (0.17) & & & & \\
\hline \multicolumn{7}{|l|}{ Hormone concentration } \\
\hline IGF-1, ng/mL & $176.79^{b}$ & $159.00^{\mathrm{a}}$ & 6.02 & 0.028 & -0.222 & $(140-183)$ \\
\hline Growth hormone, $\mathrm{ng} / \mathrm{mL}$ & $22.54^{\mathrm{b}}$ & $16.55^{\mathrm{a}}$ & 1.91 & $<0.001$ & -0.766 & $(10-23)$ \\
\hline \multicolumn{7}{|c|}{ Biomarker of protein metabolism } \\
\hline Total protein, g/dL & 7.39 & 7.84 & 0.18 & 0.123 & 0.377 & $(6-9)$ \\
\hline Albumin, $\mathrm{g} / \mathrm{dL}$ & $3.89^{\mathrm{a}}$ & $4.02^{b}$ & 0.14 & 0.591 & 0.408 & $(\overline{3-5})$ \\
\hline PUN, mg/dL & $16.06^{\mathrm{a}}$ & $19.27^{\mathrm{b}}$ & 0.24 & 0.031 & 0.509 & $(12-28)$ \\
\hline Creatinine, $\mathrm{mg} / \mathrm{dL}$ & $1.02^{\mathrm{b}}$ & $0.69^{\mathrm{a}}$ & 0.01 & 0.013 & -0.570 & (0.4-1) \\
\hline \multicolumn{7}{|c|}{ Biomarker of energy and lipid metabolism } \\
\hline Glucose, $\mathrm{mg} / \mathrm{dL}$ & 64.23 & 64.08 & 1.68 & 0.952 & -0.015 & $(53-74)$ \\
\hline Triglycerides, $\mathrm{mg} / \mathrm{dL}$ & $36.81^{\mathrm{a}}$ & $44.29^{\mathrm{b}}$ & 2.44 & 0.045 & 0.477 & $(25-50)$ \\
\hline Cholesterol, $\mathrm{mg} / \mathrm{dL}$ & 119.95 & 144.49 & 9.97 & 0.083 & 0.419 & $(105-178)$ \\
\hline NEFA, $\mu \mathrm{mol} / \mathrm{L}$ & 27.08 & 29.47 & 4.38 & 0.720 & 0.268 & $(19-43)$ \\
\hline BHBA, $\mathrm{mmol} / \mathrm{L}$ & 0.25 & 0.24 & 0.01 & 0.523 & -0.161 & $(0.2-0.3)$ \\
\hline \multicolumn{7}{|l|}{ Plasma mineral level } \\
\hline Calcium, mg/dL & 10.06 & 10.30 & 3.95 & 0.664 & 0.110 & $(8-13)$ \\
\hline Phosphorus, mg/dL & 5.91 & 5.94 & 0.36 & 0.939 & 0.019 & $(4-7)$ \\
\hline
\end{tabular}

${ }^{\beta}$ Mean with different superscript in a row differs significantly $(\mathrm{P}<0.05)$; ${ }^{¥}$ Pearson square; ${ }^{€}$ Within normal physiological range according to the literature correlation coefficient; RFI - residual feed intake; SEM - standard error of mean; PUN - plasma urea nitrogen; NEFA - non-esterified fatty acid; BHBA - beta-hydroxy butyric acid

\section{Discussion}

The TMR fed during the experimental period contained $128 \mathrm{~g} \mathrm{CP} / \mathrm{kg} \mathrm{DM}, 572 \mathrm{~g} / \mathrm{kg}$ DM TDN, and $2.16 \mathrm{Mcal} / \mathrm{kg} \mathrm{DM} \mathrm{ME}$, which fulfilled the nutrient requirements (NRC, 2001) for the growing Sahiwal calves enrolled in this study.

Performance and nutrient digestibility. Over the course of the 90 day trial period, low RFI calves consumed $26 \%$ less feed than high RFI calves, a value that agrees very 
well with the $19 \%$ differences in the Murrah buffalo calves divergently selected for low $(-0.14 \mathrm{~kg} / \mathrm{d})$ and high RFI $(0.14 \mathrm{~kg} / \mathrm{d})$, with no difference in body weight gain (SHARMA et al., 2016). NASCIMENTO et al. (2015) noted that low RFI $(\leq 0.128 \mathrm{~kg} / \mathrm{d})$ Nellore cattle consumed $7.2 \mathrm{~kg} \mathrm{DM} / \mathrm{d}$, which was $14.0 \%$ less feed than animals with high RFI $(>0.135$ $\mathrm{kg} / \mathrm{d})$, although no significant differences in ADG were observed among RFI classes. A $10 \%$ reduction in DMI by the low RFI Murrah buffalo calves compared to high RFI $(-0.20$ vs. $0.23 \mathrm{~kg} \mathrm{DM} / \mathrm{d}$ ), despite no differences in body weight gain, was reported by BOSE et al. (2014). Accordingly, no differences in ADG were detected between Sahiwal calves of low and high RFI despite high RFI calves consuming 19.6\% more feed than low RFI calves (SHARMA et al., 2014). Results of low DMI in more efficient animals were also found by BONILHA et al. (2013), who detected a difference of $0.656 \mathrm{~kg} / \mathrm{d}$ between low and high RFI Nellore animals with similar body size and growth rate. FITZSIMONS et al. (2014) observed similar ADG among low and high RFI heifers (-0.43 vs. $0.44 \mathrm{~kg} / \mathrm{d})$, even though high RFI beef heifers consumed 16\% more feed DM than low RFI heifers. Other studies also reported lower feed intake and similar growth rate in low RFI animals than high RFI animals (KELLY et al., 2010; SMITH et al., 2010; SOBRINHO et al., 2011; STEYN et al., 2014). In this regard, CRUZ et al. (2010), BONILHA et al. (2013), NASCIMENTO et al. (2015) and SHARMA et al. (2016) reported a positive correlation between RFI and feed intake, whereas the correlation between RFI and body weight gain was 0 . The lower feed intake in the low RFI group without alteration in growth rate indicated that these Sahiwal calves were more efficient in utilizing feed nutrients for tissue growth as a result of the higher metabolizability of the consumed feed.

RFI takes into account the energy requirements for maintenance and production, and is more sensitive to variations in the individual energy efficiency of the animals (DITTMAR, 2007). More efficient calves (low RFI) required 35\% less MEm compared to less efficient calves (high RFI), despite no difference observed for MEg between the two groups. SHARMA et al. (2016) observed 12.5 vs. $16.7 \mathrm{MJ} / \mathrm{d} \mathrm{MEm}$ and 7.5 vs. $7.9 \mathrm{MJ} / \mathrm{d}$ MEg, respectively in low and high RFI Murrah buffalo calves, which is in accordance with the findings of our study. BOSE et al. (2014) previously reported that more efficient calves had lower ME requirements for body maintenance than the less efficient calves whereas, the ME required for gain was similar between the two groups. Lower energy requirements for body maintenance in more efficient animals were also reported by JOHNSON et al. (2003), PITCHFORD (2004) and RICHARDSON and HERD (2004). The differences in feed intake between animals could affect RFI status because as feed intake increases, the amount of energy needed for digestion also increases, thereby increasing the maintenance requirement (ODDY and HERD, 2001). Differences in energy expenditure associated with physical activity and feeding pattern accounted for 10 and $2 \%$, respectively, of the variations in energetic efficiency (HERD and ARTHUR, 2009). 


\section{A. K. Singh et al.: Efficiency of calves varying in RFI}

The digestibility coefficients for the majority of the nutrients were higher for the low RFI group as compared to the high RFI group, except for CP and EE, which were similar in all the groups (SHARMA et al., 2014). NKRUMAH et al. (2006) observed 6\% higher apparent digestibility of DM in the low RFI group than the high RFI group, indicating that animals with low RFI are more efficient in nutrient utilization than those with a high RFI. RICHARDSON et al. (2001) observed digestibility estimates in growing cattle divergently selected for low and high RFI after one generation. When fed roughage-based diets, low RFI bulls and heifers tended to have higher digestibility compared to the high RFI bulls and heifers. However, similar nutrient digestibility between low and high RFI animals was observed by CRUZ et al. (2010), BISITHA et al. (2014), BOSE et al. (2014) and SHARMA et al. (2016), which might be due to the closer variation in RFI between groups with low and high RFI.

Feed efficiency measures and ingestive behavior. The better feed efficiency in low RFI calves compared to high RFI calves have also been shown through traditional measures of feed efficiency. Low RFI animals showed greater residual weight gain, residual intakeweight gain, feed efficiency, and PEG, as well as lower FCR, than animals with medium and high RFI, respectively (NASCIMENTO et al., 2015). BOSE et al. (2014), SHARMA et al. 2014 and SHARMA et al. 2016 also noted better FCR in low RFI animals than high RFI animals. BASARAB et al. (2003), NKRUMAH et al. (2006), and KAYSER and HILL (2013) found differences of $9 \%, 18 \%$, and 17\%, respectively, in FCR between animals classified as low RFI and high RFI. KELLY et al. (2014) observed a negative correlation between RFI and FCE, but not with ADG, KR, or RGR. A weak positive correlation of 0.12 between KR and RFI was estimated, as well as a strong negative correlation of -0.64 between KR and FCR (STEYN et al., 2014). The correlation between RFI and FCR was estimated to be 0.67 , which is similar to previously published estimates, ranging from 0.57 to 0.85 (ARTHUR et al., 2001a, 2001b; NKRUMAH et al., 2004; VAN DER WESTHUIZEN et al., 2004). These findings agree with ours, indicating that applying selection pressure for FCR or FCE would likely lead to an increase in mature size, and thus an increase in maintenance energy and feed requirements.

The feeding behavior of animals may be altered by physical activity which thus influences total energy expenditure and feed efficiency (SUSENBETH et al., 1998). With respect to the ingestive behavior data, less efficient calves (high RFI) consumed more feed, therefore, spent more time in feeding, rumination, and chewing compared to more efficient calves (high RFI). Similarly, KELLY et al. (2010) found that low RFI animals spent less time and energy in this activity and more time in sedentary activities, possibly saving energy that is directed towards weight gain. A shorter bunk visit duration in low RFI animals than high RFI animals was also noted by NKRUMAH et al. (2006), LANCASTER et al. (2009), and McGEE et al. (2014). High-efficiency animals used less 
energy in the physiological processes involved in maintenance, resulting in more net energy available for tissue accretion (CASTRO BULLE et al., 2007). KELLY et al. (2014) observed positive relationships between feeding events and DMI $(r=0.31)$, ADG $(r=$ $0.28)$, and RFI $(\mathrm{r}=0.24)$, but not with the gain: feed ratio in finishing heifers. Similarly, the present study observed a trend toward a positive relationship of RFI with both the number of daily feeding events and the eating rate. McGEE et al. (2014), NKRUMAH et al. (2007), and LANCASTER et al. (2009) reported a moderate correlation between RFI and bunk visit frequency (0.29), and KAYSER and HILL (2013) found a moderate correlation between RFI and DMI per visit in Angus (0.52) and Hereford (0.36) cattle.

RFI and plasma metabolites. The systemic concentrations of key blood metabolites associated with feed intake, growth, nutrient partitioning and utilization are potential physiological markers of feed efficiency (RICHARDSON et al., 2004; NKRUMAH et al., 2007) and may explain, in part, the biological variations in RFI.

IGF-1, a hormone secreted by the liver which can influence growth and feed efficiency, has been genetically (MOORE et al., 2005) and phenotypically (BROWN et al., 2004) correlated with RFI and might prove useful for feed efficiency traits in growing cattle (JOHNSTON et al., 2002). With respect to the blood concentrations of IGF-1, significant differences were observed among RFI classes, with higher concentrations of this hormone in animals with low RFI (KELLY et al., 2011). SHARMA et al. (2016) observed higher IGF-1 concentrations in low RFI Murrah buffalo calves compared to high RFI calves. BRANCO et al. (2013) and DUDI and DATT (2015) also reported higher IGF-1 concentrations in the low RFI group than the high RFI group. The negative correlation between IGF-1 and RFI shows that the more efficient calves had higher concentrations of IGF-1 since these calves deposited more lean mass than less efficient calves (WALKER et al., 2010). IGF-1 stimulates protein synthesis in muscle by promoting somatic cell growth (DAFTARY and GORE, 2005).

The growth hormone increases the synthesis of muscle tissue and frequently reduces deposition of body fat, and also inhibits insulin-induced suppression of hepatic gluconeogenesis (CLEMMONS, 2004). This causes a measurable increase in growth rate and improved feed efficiency in low RFI animals. In the findings of the present study, Sahiwal calves with low RFI showed higher plasma concentrations of growth hormone compared to high RFI calves. Similar to the findings of the present study, SHARMA et al. (2016) observed higher GH concentrations in low RFI Murrah buffalo calves compared to high RFI calves, over the course of a $99 \mathrm{~d}$ trial period. In contrast, a similar concentration of GH was reported by DUDI and DATT (2015) in Sahiwal calves, and by XI and WANG (2016) in lactating Holstein cows of both low and high RFI groups.

The plasma metabolites, such as total protein, albumin, PUN and creatinine, were used as biomarkers of body protein metabolism and muscle accretion in calves in the 


\section{A. K. Singh et al.: Efficiency of calves varying in RFI}

present study. The results of plasma total protein and albumin concentration in the current study confirm previous findings for Murrah buffalo calves (SHARMA et al., 2016). The plasma total protein levels were similar in low and high RFI animals which are in agreement with a study of DUDI and DATT (2015) conducted in female Sahiwal calves. NASCIMENTO et al. (2015) observed similar plasma total protein concentration in low $(63.80 \mathrm{~g} / \mathrm{L})$, medium $(64.20 \mathrm{~g} / \mathrm{L})$ and high $(63.80 \mathrm{~g} / \mathrm{L})$ RFI Nellore cattle over the period of an 84 day study. LAWRENCE et al. (2012), who evaluated blood variables in heifers of different RFI classes, also reported no differences in the blood concentrations of total protein. However, PAULA et al. (2013) in lamb, BEZERRA et al. (2013) in steers, and SHARMA et al. (2014) in calves, reported higher concentrations of plasma total protein for groups with a high RFI. PAULA et al. (2013) detected differences in the serum albumin levels among the RFI efficiency classes, with the most efficient animals showing the lowest concentrations, which could be due to efficient protein deposition in low RFI animals.

Serum urea concentration is a marker of protein intake and digestion, degradation of protein sources, and energy availability in the rumen (ROSELER et al., 1993). Animals presenting lower serum urea concentrations are probably more efficient in dietary protein and energy utilization (HASSAN and SAEED, 2012). Variations in the rate of protein degradation among low and high RFI animals might be another reason for the higher PUN concentration in high RFI calves. THEIS (2002) observed higher concentrations of BUN in less efficient steers (high RFI), which supports the findings of our study. SHARMA et al. (2014) in Sahiwal calves, KELLY et al. (2014) in Limousin $\times$ Friesian heifers, DUDI and DUTT (2015) in Murrah buffalo calves and NASCIMENTO et al. (2015) in Nellore cattle also observed higher BUN concentrations in the low RFI group compared to the high RFI group. This may be ascribed to the greater protein intake in high RFI animals, a greater rate of body protein degradation, or deviations in the supply of AA, due in part to variations in the efficiency of microbial protein production in the rumen (KAHN et al., 2000).

Serum creatinine is another indicator of protein metabolism in ruminants, and has been proposed as a marker for muscle mass in a steady state (CALDEIRA et al., 2007). Since creatinine is a non-protein nitrogenous substance produced during muscle metabolism, its concentration in blood should not be influenced by age or sex (GREGORY et al., 1999). Plasma creatinine level was negatively associated with fat depth (CLARKE et al., 1996) and was found to be negatively correlated with RFI (HERD and ARTHUR, 2009). Similar to the findings of the present study, PAULA et al. (2013) and RICHARDSON et al. (2004) observed a negative correlation $(r=-0.45)$ between RFI and the mean concentration of serum creatinine, and a comparison of the two RFI groups showed significant differences for this variable. However, no differences in the levels of blood creatinine between the 
low and high RFI groups were observed by SHARMA et al. (2016) and BOSE et al. (2014) in Murrah buffalo calves, or by NASCIMENTO et al. (2015) in Nellore cattle.

In the present study, plasma metabolites, such as glucose, cholesterol, triglycerides, NEFA and BHBA were used as biomarkers lipid and energy metabolism. No differences in plasma glucose concentrations between low and high RFI calves is in accordance with the findings of DUDI and DATT (2015). NASCIMENTO et al. (2015) in Nellore cattle also reported similar blood glucose levels in low, medium and high RFI groups. SHARMA et al. (2016) found no association between RFI and blood glucose concentration, and observed similar glucose concentrations in low, medium and high RFI Sahiwal calves. LAWRENCE et al. (2012) and KELLY et al. (2010), investigating the sires and heifers of taurine breeds, also reported similar plasma glucose concentrations in all RFI classes. The glucose level in experimental calves was within normal physiological range in the report by SHARMA et al. (2014) in Sahiwal calves.

Differences in blood cholesterol concentration between low and high RFI cattle have not been well established, and limited literature is available on this aspect. In low and high RFI Ile de France lambs, PAULA et al. (2013) found similar blood cholesterol and triglycerides levels in both groups. However, RAUW et al. (2007) noted a weak negative correlation in pigs $(\mathrm{r}=-0.09)$ between RFI and blood cholesterol levels. LAWRENCE et al. (2012), who evaluated blood variables in heifers of different RFI groups, observed similar blood concentrations of triglycerides in low and high RFI groups. The lower serum triglyceride concentrations observed in low RFI Sahiwal calves, compared to high RFI calves, are probably due to the lower deposition of fat in the carcass, since more efficient calves deposit more lean muscle mass (NASCIMENTO et al., 2015).

BHBA and NEFA are the product of tissue fatty acid catabolism, and systemic concentrations increase in proportion to the degree of fat mobilization. These two biomarkers are used to access the energy balance of animals. In this study, levels of BHBA and NEFA were within physiological range, as observed by KUMAR et al. (2013), showing that the experimental calves were in a positive energy balance. Limited information is available regarding the circulatory concentrations of BHBA and NEFA in low and high RFI calves. KELLY et al. (2014) found a positive association of BHBA with DMI $(r=0.24)$ and RFI $(r=0.40)$, whereas NEFA concentrations were unrelated to intake, growth or RFI in finishing heifers.

The plasma concentrations of $\mathrm{Ca}$ and $\mathrm{P}$ were similar in calves of both groups. No information is available regarding the association of blood concentrations of $\mathrm{Ca}$ and $\mathrm{P}$ with RFI. 


\section{A. K. Singh et al.: Efficiency of calves varying in RFI}

\section{Conclusion}

The results presented have identified many differences in the performance and metabolism of Sahiwal calves following selection for low and high RFI. When considering Sahiwal calves with low and high RFI, the low RFI calves are more efficient because they eat less feed, spent less time in feeding events, and require less metabolizable energy for body maintenance. Significant variations in RFI exist in plasma concentrations of albumin, globulin, PUN, creatinine, triglycerides, IGF-1 and GH. The findings of blood metabolites suggest the relationship of RFI with body metabolism, and should provide a basis for further research to better characterize the relationships between these factors, and to identify physiological indicators that could be predictive of RFI. Eventually selection of Sahiwal calves with low RFI will therefore be more economical than calves with high RFI, as low RFI calves consume less feed while growing at a similar rate.

\section{Acknowledgements}

Financial assistance for the research was provided under a University Grant supported by the Indian Council of Agricultural Research, New Delhi, India. We thank the Faculty and Staff of the Department of Animal Nutrition and Instructional Livestock Farm Complex, College of Veterinary Science and Animal Husbandry, DUVASU, Mathura.

\section{References}

ANITHA, A., S. K. RAO, J. V. RAMANA, S. P. V. V. Reddy (2005): Body conditions score and its relation to age and physical parameters in crossbred cows. Indian Vet. J. 82, 305-308.

AOAC (2005): Official Methods of Analysis of the Association of Official Analytical Chemists, $18^{\text {th }}$ ed. Arlington (USA), pp. 24-44.

ARCHER, J. A., P. F. ARTHUR P, R. M. HERD, P. F. PARNELL, W. S. PITCHFORD (1997): Optimum post weaning test for measurement of growth rate, feed intake, and feed efficiency in British breed cattle. J. Anim. Sci. 75, 2024-2032.

DOI: $10.2527 / 1997.7582024 x$

ARCHER, J. A., P. F. ARTHUR, R. M. HERD, E. C. RICHARDSON (1998): Genetic variation in feed efficiency and its component traits, In: Proceedings of the $6^{\text {th }}$ World Congress on Genetics Applied to Livestock Production, Armidale, NSW (Australia). pp. 25, 81-84.

ARTHUR, P. F., J. A. ARCHER, D. J. JOHNSTON, R. M. HERD, E. C. RICHARDSON, P. F. PARNELL (2001a): Genetic and phenotypic variance and covariance components for feed intake, feed efficiency and other post-weaning traits in Angus cattle. J. Anim. Sci. 3, 59-66.

DOI: $10.2527 / 2001.79112805 x$

ARTHUR, P. F., J. A. ARCHER, R. M. HERD, G. J. MELVILLE (2001b): Response to selection for net feed intake in beef cattle. In: Proceeding of the Association for the Advancement of Animal Breeding and Genetics, Queenstown (New Zealand). pp. 14, 135-138. 
A. K. Singh et al.: Efficiency of calves varying in RFI

BASARAB, J. A., M. A. PRICE, J. L. AALHUS, E. K. OKINE, W. M. SNELLING, K. L. LYLE (2003): Residual feed intake and body composition in young growing cattle. Can. J. Anim. Sci. 83, 189-204.

DOI: $10.4141 / \mathrm{a} 02-065$

BEZERRA, L. R., J. L. R. SARMENTO, S. G. NETO, N. R. O. DE PAULA, R. L. OLIVEIRA, M. F. R. WAGNER (2013): Residual feed intake: a nutritional tool for genetic improvement. Trop. Anim. Health Prod. 45, 1649-1661.

DOI: $10.1007 / \mathrm{s} 11250-013-0435-\mathrm{y}$

BONILHA, E. F. M., R. H. BRANCO, S. F. M. BONILHA, F. L. ARAÚJO, E. MAGNANI, M. E. Z. MERCADANTE (2013): Body chemical composition of Nellore bulls with different residual feed intakes. J. Anim. Sci. 91, 3457-3464.

DOI: $10.2527 /$ jas.2012-5437

BOSE, B. K. S., S. S. KUNDU, N. T. B. THO, V. K. SHARMA, U. B. SONTAKKE (2014): Residual feed intake as a feed efficiency selection tool and its relationship with feed intake, performance and nutrient utilization in Murrah buffalo calves. Trop. Anim. Health Prod. 46, 615-621.

DOI: $10.1007 / \mathrm{s} 11250-014-0536-2$

BRANCO, R. H., C. F. NASCIMENTO, E. MAGNANI, L. F. OLIVEIRA, S. F. M. BONILHA, J. N. S. G. CYRILLO (2013): Residual feed intake and hormonal parameters in Nellore cattle. J. Dairy Sci. 96, 321-332.

BROWN, E. G., G. E. CARSTENS, J. T. FOX, M. B. WHITE, K. O. CURLEY, T. M. BRYAN, L. J. SLAY, JR. T. H. WELSH, R. D. RANDEL, J. W. HOLLOWAY, D. H. KEISLER (2004): Physiological indicators of performance and feed efficiency traits in growing steers and bulls. In: Proceeding of the Southern Section, American Society of Animal Science, Tulsa, Oklahoma (USA), p. 13.

CALDEIRA, R. M., A. T. BELO, C. C. SANTOS (2007): The effect of body condition score on blood metabolites and hormonal profiles in ewes. Small Rumin. Res. 68, 233-241.

DOI: 10.1016/j.smallrumres.2005.08.027

CASTRO Bulle, F. C. P., P. V. PAUlino, A. C. SANCHES, R. D. SAINZ (2007): Growth, carcass quality, and protein and energy metabolism in beef cattle with different growth potentials and residual feed intake. J. Anim. Sci. 85, 928-936.

DOI: $10.2527 /$ jas.2006-373

CLARKE, J. M., D. B. BINNIE, K. R. JONES, C. R. MOWAR, R. W. PURCHAS, A. E. ULJEE (1996): Respectabilities of blood plasma metabolites and their association with leanness in genotypes showing a wide divergence in carcass composition. In: Proceeding of New Zealand Society of Animal Production 56, 180-183.

CLEMMONS, D. R. (2004): The relative roles of growth hormone and IGF-1 in controlling insulin sensitivity. J. Clin. Invest. 113, 25-27.

DOI: $10.1172 /$ jci200420660

Vet. arhiv 89 (4), 481-503, 2019 
CRUZ, G. D., J. A. RODRÍGUEZ-SÁNCHEZ, J. W. OLTJEN, R. D. SAINZ (2010): AngusHereford steers housed in individual or group pens Performance, residual feed intake, digestibility, carcass traits, and profitability. J. Anim. Sci. 88, 324-329.

DOI: $10.2527 /$ jas.2009-1932

DAFTARY, S. S., A. C. GORE (2005): IGF-1 in the brain as a regulator of reproductive neuroendocrine function. Exp. Biol. Med. 230, 292-306.

DOI: $10.1177 / 153537020523000503$

DITTMAR III R. O. (2007): Determining biological sources of variation in residual feed intake in Brahman heifers during confinement feeding and on pasture. M.Sc. Thesis, Texas A\&M University.

DUDI, K., C. DATT (2015): Relationship of residual feed intake with blood metabolites and hormones in Sahiwal female calves. Forage Res. 41, 40-45.

FITZHUGH, H. A., C. S. S. TAYLOR (1971): Genetic analysis of degree of maturity. J. Anim. Sci. $33,717-725$.

FITZSIMONS, C., D. A. KENNY, M. McGEE (2014): Visceral organ weights, digestion and carcass characteristics of beef bulls differing in residual feed intake offered a high concentrate diet. Animal 8, 949-959.

DOI: $10.1017 / \mathrm{s} 1751731114000652$

GREGORY L., JR. E. H. BIRGEL, R. M. S. MIRANDOLA, W. P. ARAÚJO, E. H. BIRGEL (1999): Reference values of the enzymatic activities of the aspartate aminotransferase and gamma glutamyltransferase of Jersey breed. The influence of age and sexual factors, and of the infection by the bovine leukosis virus. Arq. Bras. Med. Vet. Zootec. [online]. 51, 515-522. ISSN 0102-0935.(in Portuguese).

DOI: $10.1590 / \mathrm{s} 0102-09351999000600001$

HASSAN, S. A., A. A. SAEED (2012): Effect of feeding different levels of dietary protein with high or low rumen degradable: undegradable dietary nitrogen on Awassi lambs performance 3-selected biochemical parameters. J. Nat. Sci. 15, 36-45.

HEGARTY, R. S., J. P. GOOPY, R. M. HERD, D. McCORKELL (2007): Cattle selected for lower residual feed intake have reduced daily methane production. J. Anim. Sci. 85, 1479-1486.

DOI: $10.2527 /$ jas.2006-236

HERD, R. M., P. F. ARTHUR (2009): Physiological basis for residual feed intake. J. Anim. Sci. 87, 64-71.

JOHNSON, D. E., C. L. FERRELL, T. G. JENKINS (2003): The history of energetic efficiency research: Where have we been and where are we going. J. Anim. Sci. 81, 27-38.

JOHNSTON, D. J., R. M. HERD, M. J. KADEL, H. U. GRASER, P. F. ARTHUR, J. A. ARCHER (2002): Evidence of IGF-1 as a genetic predictor of feed efficiency traits in beef cattle. In: Proceeding of 7th World Congress on Genetics Applied to Livestock Production, Montpellier (France), pp. 1-4. 
A. K. Singh et al.: Efficiency of calves varying in RFI

KAHN, L. P., R. A. LENG, L. R. PIPER (2000): Rumen microbial yield from sheep genetically different for fleece weight. Asian-Australian J. Anim. Sci. 13C, 137.

KAYSER, W., R. A. HILL (2013): Relationship between feed intake, feeding behaviors, performance, and ultrasound carcass measurements in growing purebred Angus and Hereford bulls. J. Anim. Sci. 91, 5492-5499.

DOI: $10.2527 /$ jas.2013-6611

KELLY, A. K., M. McGEE, JR. D. H. CREWS, A. G. FAHEY, A. R. WYLIE, D. A. KENNY (2010): Effect of divergence in residual feed intake on feeding behavior, blood metabolic variables and body composition traits in growing beef heifers. J. Anim. Sci. 88, 109-123.

DOI: $10.2527 /$ jas.2009-2196

KELLY, A. K., M. McGEE, JR. D. H. CREWS, C. O. LYNCH, A. R. WYLIE, R. D. EVANS, D. A. KENNY (2011): Relationship between body measurements, metabolic hormones, metabolites and residual feed intake in performance tested pedigree beef bulls. Livest. Sci. 135, 8-16.

DOI: $10.1016 /$ j.livsci.2010.05.018

KELLY, A. K., M. McGEE, JR. D. H. CREWS, T. SWEENEY, T. M. BOLAND, D. A. KENNY (2014): Repeatability of feed efficiency, carcass ultrasound, feeding behavior, and blood metabolic variables in finishing heifers divergently selected for residual feed intake. J. Anim. Sci. $88,3214-3225$.

DOI: $10.2527 /$ jas.2009-2700

KNOTT, S. A., L. J. CUMMINS, F. R. DUNSHEA, B. J. LEURY (2010): Feed efficiency and body composition are related to cortisol response to adrenocorticotropin hormone and insulininduced hypoglycaemia in rams. Dom. Anim. Endoc. 39, 137-146.

DOI: 10.1016/j.domaniend.2010.03.003

KOCH, R. M., L. A. SWIGER, D. CHAMBERS, K. E. GREGORY (1963): Efficiency of feed use in beef cattle. J. Anim. Sci. 22, 486-494.

DOI: $10.2527 /$ jas $1963.222486 x$

KOOTS, K. R., J. P. GIBSON, C. SMITH, J. W. WILTON (1994): Analyses of published genetic parameter estimates for beef production traits. 1. Heritability Anim. Breed. 62, 309-338.

KUMAR, M., H. KAUR, A. K. TYAGI, N. J. KEWALRAMANI, V. MANI, R. S. DEKA, V. K. SHARMA, G. CHANDRA, A. K. DANG (2013): Effect of feeding inorganic chromium on growth performance, endocrine variables, and energy metabolites in winter-exposed buffalo calves (Bubalus bubalis). Biol. Trace. Elem. Res. 155, 352-360.

DOI: $10.1007 / \mathrm{s} 12011-013-9808-3$

LANCASTER, P. A., G. E. CARSTENS, D. H. CREWS JR., T. H. WELSH, JR. T. D. A. FORBES, D. W. FORREST, L. O. TEDESCHI, R. D. RANDEL, F. M. ROUQUETTE (2009): Phenotypic and genetic relationships of residual feed intake with performance and ultrasound carcass traits in brangus heifers. J. Anim. Sci. 87, 3887-3896.

DOI: $10.2527 /$ jas.2009-2041

Vet. arhiv 89 (4), 481-503, 2019 
A. K. Singh et al.: Efficiency of calves varying in RFI

LAWRENCE, P., D. A. KENNY, B. EARLEY, M. McGEE M (2012): Grazed grass herbage intake and performance of beef heifers with predetermined phenotypic residual feed intake classification. J. Anim. Sci. 6, 1648-1661.

DOI: $10.1017 / \mathrm{s} 1751731112000559$

McGEE, M., J. A. RAMIREZ, G. E. CARSTENS, W. J. PRICE, J. B. HALL, R. A. HILL (2014): Relationships of feeding behaviors with efficiency in RFI-divergent Japanese Black cattle. J. Anim. Sci. 92, 3580-3590.

DOI: $10.2527 /$ jas.2013-7360

MISSIO, R. L., I. L. BRONDANI, D. C. ALVES FILHO, M. F. SILVEIRA, L. S. FREITAS, J. RESTLE (2010): Ingestive behavior of feedlot finished young bulls fed different concentrate levels in the diet. Rev. Brasileira de Zoot. 39, 1571-1578 (in Portuguese).

DOI: $10.1590 / \mathrm{S} 1516-35982010000700025$

MOORE, K. L., D. J. JOHNSTON, H. U. GRASER, R. HERD (2005): Genetic and phenotypic relationships between insulin-like growth factor-I (IGF-I) and net feed intake, fat, and growth traits in Angus beef cattle. Aust. J. Agric. Res. 56, 211-218.

DOI: $10.1071 / \operatorname{ar} 04248$

NASCIMENTO, C. F., R. H. BRANCO, S. F. M. BONILHA, J. N. S. G. CYRILLO, J. A. NEGRAO, M. E. Z. MERCADANTE (2015): Residual feed intake and blood variables in young Nellore cattle. J. Anim. Sci. 93, 1318-1326.

DOI: $10.2527 /$ jas.2014-8368

NGUYEN, N. H., C. P. McPHEE, C. M. WADE (2005): Responses in residual feed intake in lines of Large White pig selected for growth rate on restricted feeding (measured on ad libitum individual feeding). Anim. Breed. Gen. 122, 264-270.

DOI: 10.1111/j.1439-0388.2005.00531.x

NIANP (2013): Vision 2050, National Institute of Animal Nutrition and Physiology. Bangalore (India).

NKRUMAH, J. D., E. K. OKINE, G. W. MATHISON, K. SCHMID, C. LI, J. A. BASARAB, M. A. PRICE, Z. WANG, S. S. MOORE (2006): Relationships of feedlot feed efficiency, performance, and feeding behavior with metabolic rate, methane production, and energy partitioning in beef cattle. J. Anim. Sci. 84, 145-153.

DOI: $10.2527 / 2006.841145 \mathrm{x}$

NKRUMAH, J. D., E. L. SHERMAN, C. LI, E. MARQUES, D. H. CREWS, R. BARTUSIAK, B. MURDOCH, Z. WANG, J. A. BASARAB, S. S. MOORE (2007): Primary genome scans to identify putative quantitative trait loci for feedlot growth rate, feed intake, and feed efficiency of beef cattle. J. Anim. Sci. 85, 3170-3181.

DOI: $10.2527 /$ jas.2007-0234

NKRUMAH, J. D., J. A. BASARAB, M. A. PRICE, E. K. OKINE, A. AMMOURA, S. GUERCIO, C. HANSEN, C. LI, B. BENKEL, B. MURDOCH, S. S. MOORE (2004): Different measures 
A. K. Singh et al.: Efficiency of calves varying in RFI

of energetic efficiency and their phenotypic relationships with growth, feed intake, and ultrasound and carcass merit in hybrid cattle. J. Anim. Sci. 82, 2451-2459.

DOI: $10.2527 / 2004.8282451 \mathrm{x}$

NRC (2001): Nutrient requirements of dairy cattle, $7^{\text {th }}$ revised EDN. National Academy Press, Washington, DC (USA), pp. 13-17.

ODDY, V. H., R. M. HERD (2001): Potential mechanisms for variation in efficiency of feed utilisation in ruminants. In: Proceeding Feed Efficiency Workshop, Armidale (UK), pp. 30-34.

PAUlA, E. F. E. D., D. F. D. SOUZA, A. L. G. MONTEIRO, M. H. D. A. SANTANA, S. GILAVERTE, JR. P. ROSSI, R. L. DITTRICH (2013): Residual feed intake and hematological and metabolic blood profiles of IedeFrance lambs. R. Bras. Zootec. 42, 806-812.

DOI: $10.1590 / \mathrm{s} 1516-35982013001100007$

PITCHFORD, W. S. (2004): Genetic improvement of feed efficiency of beef cattle: What lessons can be learnt from other species. Aust. J. Exp. Agric. 44, 371-382.

DOI: $10.1071 /$ ea02111

RAUW, W. M., O. PORTOLE'S, D. CORELLA, J. SOLER, J. REIXACH, J. TIBAU, J. M. PRAT, I. DIAZ, L. GO'MEZ-RAYA (2007): Behaviour influences cholesterol plasma levels in a pig model. J. Anim. Sci. 1, 865-871.

DOI: $10.1017 / \mathrm{s} 1751731107000018$

RICHARDSON, E. C., R. M. HERD (2004): Biological basis for variation in residual feed intake in beef cattle. 2. Synthesis of results following divergent selection. Aust. J. Exp. Agric. 44, 431-440.

DOI: $10.1071 /$ ea02221

RICHARDSON, E. C., R. M. HERD, J. A. ARCHER, P. F. ARTHUR (2004): Metabolic differences in Angus steers divergently selected for residual feed intake. Aust. J. Exp. Agric. 44, 441-452. DOI: $10.1071 /$ ea02219

RICHARDSON, E. C., R. M. HERD, V. H. ODDY, J. M. THOMPSON, J. A. ARCHER, P. F. ARTHUR (2001): Body composition and implications for heat production of Angus steer progeny of parents selected for and against residual feed intake. Aust. J. Exp. Agric. 41, 10651072 .

DOI: $10.1071 / \mathrm{ea} 00095$

ROSELER, D. K., J. D. FERGUSON, C. J. SNIFFEN, J. HERREMA (1993): Dietary protein degradability effects on plasma and milk urea nitrogen and milk nonprotein nitrogen in Holstein cows. J. Dairy Sci. 76, 525-534.

DOI: $10.3168 /$ jds.s0022-0302(93)77372-5

SHARMA, V. C., M. S. MAHESH, M. MOHINI, C. DATT, V. M. NAMPOOTHIRIA (2014): Nutrient utilisation and methane emissions in Sahiwal calves differing in residual feed intake. Arch. Anim. Nutr. 68, 345-357.

DOI: $10.1080 / 1745039 x .2014 .951193$

Vet. arhiv 89 (4), 481-503, 2019 
A. K. Singh et al.: Efficiency of calves varying in RFI

SHARMA, V. K., S. S. KUNDU, S. PRUSTY, C. DATT, M. KUMAR (2016): Nutrient utilisation, growth performance and blood metabolites in Murrah buffalo calves (Bubalus bubalis) divergently selected for residual feed intake. Arch. Anim. Nutr. 70, 455-469.

DOI: $10.1080 / 1745039 x .2016 .1233678$

SHIPE, W. F., G. F. SENYK, K. B. FOUNTAIN (1980): Modified copper soap solvent extraction method for measuring free fatty acids in milk. J. Dairy Sci. 63, 193-198.

DOI: $10.3168 /$ jds.s0022-0302(80)82913-4

SMITH, S. N., M. E. DAVIS, S. C. LOERCH (2010): Residual feed intake of Angus beef cattle divergently selected for feed conversion ratio. Livest. Sci. 132, 41-47.

DOI: $10.1016 /$ j.livsci.2010.04.019

SOBRINHO, T. L., R. H. BRANCO, S. F. M. BONILHA, A. M. CASTILHOS, L. A. FIGUEIREDO, A. G. RAZOOK, M. E. Z. MERCADANTE (2011): Residual feed intake and relationships with performance of Nellore cattle selected for post weaning weight. R. Bras. Zootec. 40, 929-937.

DOI: $10.1590 / \mathrm{s} 1516-35982011000400030$

STEYN, Y., E. VANMARLE-KOSTER, H. E. THERON (2014): Residual feed intake as selection tool in South African Bonsmara cattle. Livest Sci. 164, 35-38.

DOI: 10.1016/j.livsci.2014.03.007

SUSENBETH, A., R. MAYER, B. KIEHLER, O. NEUMANN (1998): Energy requirements for eating in cattle. J. Anim Sci. 76, 2701-2705.

TALAPATRA, S. K., S. C. RAY, K. C. SEN (1940): Estimation of phosphorous, chloride, calcium, sodium and potassium in food stuffs. Indian J. Vet. Sci. 10, 243-258.

THEIS, C. M. (2002): Physiological indicators of phenotypic variation in net feed efficiency of growing cattle. M.S. Thesis, College Station Texas A\&M University.

VAN DER WESTHUIZEN, R. R., J. VAN DER WESTHUIZEN, S. J. SCHOEMAN (2004): Genetic variance components for residual feed intake and feed conversion ratio and their correlations with other production traits in beef bulls. S. Afr. J. Anim. Sci. 34, 257-265.

DOI: $10.4314 /$ sajas.v34i6.3829

VAN SOEST, P. J., J. B. ROBERTSON, B. A. LEWIS (1991): Symposium: carbohydrate methodology, metabolism and nutritional implications in dairy cattle. Methods for dietary fiber, neutral detergent fiber and non starch polysaccharides in relation to animal nutrition. J. Dairy Sci. 74, 3583-3597.

DOI: $10.3168 /$ jds.s0022-0302(91)78551-2

WALKER, D. K., E. C. TITGEMEYER, T. J. BAXA, K. Y. CHUNG, D. E. JOHNSON, S. B. LAUDERT, B. J. JOHNSON (2010): Effects of ractopamine and sex on serum metabolites and skeletal muscle gene expression in finishing steers and heifers. J. Anim. Sci. 88, 1349-1357.

DOI: $10.2527 /$ jas.2009-2409 
A. K. Singh et al.: Efficiency of calves varying in RFI

WEICHSELBAUM, T. E., M. SOMOGYI (1941): The determination of ketone bodies. J. Biol. Chem. 5, 140.

XI, Y. M., G. L. WANG (2016): Biological mechanism related to differences in residual feed intake in dairy cows. Animal 10, 1311-1318.

Received: 5 March 2018

Accepted: 14 July 2019

\begin{abstract}
SINGH, A. K., M. KUMAR, V. KUMAR, D. ROY, R. KUSHWAHA, S. VASWANI, A. KUMAR: Iskorištavanje hrane, metaboliti u krvi i ponašanje pri unosu hrane u teladi sahival pasmina odabrane s obzirom na visoki ili niski ostatni unos hrane. Vet. arhiv 89, 481-503, 2019.
\end{abstract}

\title{
SAŽETAK
}

Ovo istraživanje imalo je za cilj, na temelju proizvodnje, ponašanja kod unosa hrane i metabolita u krvi, procijeniti razlike u iskorištavanju hrane između sahival teladi s niskim ostatnim unosom hrane i visokim ostatnim unosom hrane (Residual Feed Intake - RFI). Osamnaest sahival teladi ženskog spola (u dobi od 10 do -14 mjeseci i tjelesnoj masi od 100 do $125 \mathrm{~kg}$ ) hranjeno je 90 dana, ad libitum, kompletnim mješovitim obrokom. Ostatni unos hrane kretao se od -0,53 do 0,40 kg suhe tvari/d, sa srednjom vrijednošću od - $0,27 \mathrm{kod}$ sahival teladi s niskim ostatnim unosom i srednjom vrijednošću od $0,17 \mathrm{~kg}$ kod sahival teladi visokim ostatnim unosom hrane. Iako je telad s niskim ostatnim unosom hrane u odnosu na onu s visokim ostatnim unosom hrane konzumirala $26 \%$ manje suhe tvari i zahtijevala $35 \%$ manje uzdržne energije za metabolizam tijela, prirast obje skupne teladi kretao se po sličnoj stopi. Telad s niskim ostatnim unosom hrane imala je učinkovitiju hranidbu što su pokazali i standarni pokazatelji prema kojima je ta telad provela hranidbu u kraćem vremenu, uz kraće žvakanje i preživanje. U usporedbi s teladi koja ima viši ostatni unos hrane, telad s niskim ostatnim unosom hrane imala je u plazmi veće koncentracije inzulinu-sličnog faktora rasta-1 (IGF-1), hormona rasta $(\mathrm{GH})$ i kreatinina, te niže koncentracije albumina, dušika iz ureje i triglicerida. Koncentracije ukupnih proteina, glukoze, kolesterola, neesterificirane masne kiseline (NEFA), betahidroksi maslačne kiseline (BHBA), kalcija (Ca) i fosfora (P) bile su slične u obje skupine teladi. Sažeto, telad s niskim ostatnim unosom hrane iskorištavala je hranu učinkovitije, provodeći kraće vrijeme i trošeći manje energije prilikom hranjenja, a varijacije metabolita u krvi mogle bi biti posljedica razlika u metabolizmu.

Ključne riječi: učinkovitost; ponašanje pri hranjenju; metaboliti u plazmi; ostatni unos hrane; sahival pasmina 
